\title{
KAJIAN SPIRIT OF PLACE PADA PASAR LEGI KOTAGEDE YOGYAKARTA SEBAGAI KARAKTER PASAR TRADISIONAL
}

\author{
Sugesti Retno Yanti ${ }^{1}$, Anna Pudianti ${ }^{2}$ \\ ${ }^{1}$ Mahasiswa Pascasarjana Arsitektur Universitas Atma Jaya Yogyakarta \\ ${ }^{2}$ Pascasarjana Arsitektur Universitas Atma Jaya Yogyakarta \\ J. Babarsari No. 44, Yogyakarta 55281 \\ *silviagesty@gmail.com ${ }^{1}$, anna@mail.uajy.ac.id ${ }^{2}$
}

Diterima: 24-08-2020 Direview: 07-09-2020 Direvisi : 04-10-2020 Disetujui: 05-10-2020

\begin{abstract}
ABSTRAK. Pasar tradisional menjadi ruang transaksi ekonomi dengan tradisi tawar menawar antara penjual dan pembeli. Sebuah penelitian menyebutkan bahwa kearifan lokal masyarakat Kotagede berupa pendidikan atau cara belajar "srawung" salah satunya adalah Pasar, oleh karena itu penelitian ini berfokus pada Pasar Legi Kotagede untuk membuktikan pernyataan tersebut. Tujuan dari penelitian untuk mengidentifikasi srawung sebagai Spirit of Place pada Pasar Legi Kotagede. Untuk membuktikan bahwa hal tersebut merupakan keunikan khas Pasar Legi Kotagede maka perlukan pembanding. Hasil penelitian ternyata penataan layout, zonasi pedagang, toleransi, keakraban dan kerjasama antara pedagang maupun pembeli merupakan faktor-faktor yang membentuk Spirit of Place pada pasar tradisional.
\end{abstract}

Kata Kunci: karakter Pasar Tradisional, Kearifan lokal, Pasar Legi Kotagede, Spirit of Place

ABSTRACT. Traditional markets are an economic transaction space with a tradition of bargaining between sellers and buyers. A study states that the local wisdom of the Kotagede community in the form of education or how to learn "srawung" one of which is the Market. Therefore this research focuses on the Pasar Legi Kotagede to prove the statement. The purpose of this research is to identify srawung as a Spirit of Place in Kotagede Legi Market. To confirm that this is the uniqueness of the Pasar Legi Kotagede, we need a comparison. The study results turned out to be layout arrangement, trader zoning, tolerance, familiarity, and cooperation between traders and buyers are the factors that make up the Spirit of Place in traditional markets.

Keywords: Character of Traditional Market, Local Wisdom, Pasar Legi Kotagede, Spirit of Place

\section{PENDAHULUAN}

Dewasa ini pasar tradisional sudah tergeser dengan pasar modern, walaupun fungsi dan penggunanya sama tetapi segi kebersihan, keamanan dan keteraturan layout pasar modern lebih diminati oleh pengguna pasar. Pasar tradisional menjadi ruang transaksi pemenuhan kebutuhan sehari-hari yang prosesnya masih kental diwarnai suasana ekonomi pedesaan dengan tradisi tawar menawar antara penjual dan pembeli, hal ini yang membuat hubungan keakraban terjalin dan membedakan dengan pasar modern. Peninggalan Heritage di Kotagede berupa tata kota kerajaan Jawa dengan konsep Catur Gatra Tunggal yaitu konsep tata kota yang memiliki 4 bangunan dan poin pokok dalam suatu kota berupa Keraton, pasar, alun-alun dan Masjid (Kostof, 1992).

Pasar Legi atau Sarlegi yang ada di Kotagede merupakan salah satu pasar tradisional yang telah ada sebelum terbentuknya kerajaan Mataram dan menjadi pasar kerajaan sekaligus pusat perekonomian dan perdagangan" (Laws, 2016).

Pasar Legi Kotagede merupakan pasar tradisional yang masih memiliki kekhasan yaitu berupa jalinan hubungan antar sesama pedagang yang selalu menjaga kerukunan dan kenyamanan di Pasar Legi Kotagede. Kedekatan terlihat dari tatanan ruang yang tidak terlalu kaku batas ruang antar pedagang, baik pada area bagian dalam maupun luar Pasar (Rahmawati \& Kartono, 2017). Dari data Dinas Penanaman Modal dan Perizinan Kota Yogyakarta tahun 2015 terdapat 938 jumlah pedagang yang ada di pasar Legi Kotagede. Komoditi dagangan terdapat beraneka macam pedagang di Pasar Legi diantara lain pedagang jajanan pasar, pakaian, alat-alat rumah tangga, pertanian, pedagang sayur dan buah, pedagang unggas dan masih banyak yang lainnya.

Pasar tradisional adalah tempat bergaul dengan siapa saja yang datang antara pedagang, pembeli dan orang-orang yang sekedar mencari hiburan di Pasar. Dengan 
bergaul di Pasar melalui aktifitas berdagang ataupun berperan sebagai pembeli dapat membentuk relasi atau hubungan akrab, sehingga membentuk karakter khas pasar tradisional. Karakter budaya lokal membentuk identitas tempat yang berupa suasana hubungan tradisional. Kehidupan individual anggota masyarakat diwarnai oleh nilai-nilai budaya masyarakatnya.

(Garnham, 1985) dalam bukunya menyatakan bahwa setiap kota memiliki suatu keunikan, karakter, identitas, dan jiwa atau roh khusus tertentu yang menbedakan satu kota dengan kota yang lain. Spirit of Place terbentuk dengan aspek fisik (tangible) berupa situs, bangunan, lingkungan, rute, dan benda-benda buatan manusia, serta aspek non fisik (intangible) berupa memori, narasi, dokumen tertulis, festival, acara peringatan, ritual, pengetahuan tradisional, makna, tekstur, warna, dan lain sebagainya (Garnham, 1985).

Setiap Kota memiliki roh (spirit) yang mengandung nilai dan makna bagi penghuninya. Atribut lokal yang khusus terbentuk dari hubungan emosional antara manusia dan tempat yang terbentuk akibat hubungan mendalam dalam tempat tersebut (Herliana et al., 2017). Konsep Sense of place memperlihatkan hubungan manusia dengan tempat dan lingkungan tempat ia bermukim (dwelling) melalui hubungan kedekatan emosional serta maknanya (Harapan, 2011). Place merupakan suatu ruang tertentu yang terbentuk oleh hubungan antara manusia dengan setting fisik, aktivitas individu atau kelompok dan makna ruang tersebut.

Mengingat pasar merupakan salah satu pembentuk citra kota, dan pasar tradisional terutama membentuk ciri ketradisionalan tinggalan masa lalu, maka pencarian spirit of place pada Pasar Legi Kotagede merupakan studi yang penting untuk digali lebih dalam untuk mengidentifikasi kekhasan pasar tradisional.

\section{RUMUSAN MASALAH}

Ruang lingkup penelitian ini berfokus pada Pasar Legi Kotagede dengan fokus pada pertanyaan

1. Bagaimana Sprit of Place pada Pasar Legi Kotagede membentuk karakter kearifan lokal Pasar Gede?

2. Bagaimana Spirit of Place membentuk karakter kearifan lokal pada pasar tradisional?

\section{TUJUAN PENELITIAN}

Berdasarkan rumusan masalah, tujuan dari penelitian ini untuk mengidentifikasi Spirit of Place pada Pasar Legi Kotagede dan factor yang membentuk karakter pasar tradisional sebagai bagian dari citra Kotagede.

\section{METODE PENELITIAN}

Penelitian dilakukan dengan metode deskriptif melalui studi kasus pada Pasar Legi kotagede dan analisis data dengan cara kualitatif. Penelitian ini menganalisis Spirit of Place yang berpengaruh pada pola ruang pasar Legi dan karakteristik budaya kearifan lokal Kotagede. Metode pengambilan data dilakukan dengan cara observasi langsung di lapangan, dokumentasi dan studi literatur. Observasi dilakukan dengan memperhatikan layout, zonasi pedagang, serta aktifitas jual beli yang terjadi di Pasar Legi.

Observasi dilakukan pada hari Legi berdasarkan kalender jawa untuk mengamati suasana pasar dalam situasi padat pengunjung dan pedagang. Setelah mengamati dan mengkaji data hasil observasi kemudian diolah dan dianalisis. Untuk mendapatkan kesimpulan akhir, penulis melakukan studi literatur dan komparasi pasar tradisional yang lain sebagai pembanding dengan pasar Legi Kotagede. Komparasi dilakkan untuk melihat apakah kekhasan Spirit of Place yang dihasilkan di Pasar Legi Kotagede memang merupakan kekhasan yang berbeda dengan pasar tradisional yang lain. Untuk itu sebagai pembanding dipilih dua pasar yang memiliki posisi setara dengan posisi Pasar Legi Kotagede yaitu merupakan pusat aktifitas perdagangan pada pusat kota.

Tabel 1. studi komparasi literatur

\begin{tabular}{|l|l|l|l|}
\hline \multicolumn{3}{|c|}{ indikator } \\
\hline Elemen tangible (fisik) & $\begin{array}{l}\text { Elemen intangible } \\
\text { (non-fisik) }\end{array}$ \\
\hline Pasar Legi Kotagede \\
\hline lokasi & $\begin{array}{l}\text { Pasar induk } \\
\text { atau pusat di } \\
\text { Kotagede. } \\
\text { Dijadikan } \\
\text { rujukan wisata }\end{array}$ & $\begin{array}{l}\text { Karak } \\
\text { teristik }\end{array}$ & $\begin{array}{l}\text { Konsumen } \\
\text { dan } \\
\text { pedagang } \\
\text { berasal dari } \\
\text { lokal dan } \\
\text { luar daerah } \\
\text { Kotagede }\end{array}$ \\
\hline $\begin{array}{l}\text { Setting } \\
\text { ruang }\end{array}$ & $\begin{array}{l}\text { Letak los } \\
\text { pasar } \\
\text { berhimpitan. } \\
\text { Beberapa } \\
\text { pedagang } \\
\text { berdagang di }\end{array}$ & $\begin{array}{l}\text { Kegiat } \\
\text { an }\end{array}$ & $\begin{array}{l}\text { Penjual } \\
\text { sayur } \\
\text { mayur, } \\
\text { buah, } \\
\text { pakaian, } \\
\text { tanaman, }\end{array}$ \\
\hline
\end{tabular}




\begin{tabular}{|c|c|c|c|}
\hline & $\begin{array}{l}\text { jalan gang } \\
\text { ruang dalam } \\
\text { los pasar }\end{array}$ & & $\begin{array}{l}\text { dan pada } \\
\text { hari } \\
\text { pasaran } \\
\text { Legi } \\
\text { terdapat } \\
\text { pasar } \\
\text { hewan } \\
\text { unggas }\end{array}$ \\
\hline \multicolumn{4}{|c|}{ Pasar Gede Solo } \\
\hline lokasi & $\begin{array}{l}\text { Pasar induk } \\
\text { atau pusat di } \\
\text { Solo. Dijadikan } \\
\text { rujukan wisata }\end{array}$ & $\begin{array}{l}\text { Karak } \\
\text { teristik }\end{array}$ & $\begin{array}{l}\text { Konsumen } \\
\text { dan } \\
\text { pedagang } \\
\text { berasal dari } \\
\text { lokal dan } \\
\text { luar daerah } \\
\text { kebanyaka } \\
\text { n etnis } \\
\text { Cina. } \\
\end{array}$ \\
\hline $\begin{array}{l}\text { Setting } \\
\text { ruang }\end{array}$ & $\begin{array}{l}\text { Letak los } \\
\text { pasar } \\
\text { berhimpitan. } \\
\text { Beberapa } \\
\text { pedagang } \\
\text { berdagang di } \\
\text { jalan gang } \\
\text { ruang dalam } \\
\text { los pasar } \\
\end{array}$ & $\begin{array}{l}\text { Kegiat } \\
\text { an }\end{array}$ & $\begin{array}{l}\text { Penjual } \\
\text { sayur } \\
\text { mayur, } \\
\text { buah, } \\
\text { pakaian, } \\
\text { tanaman, }\end{array}$ \\
\hline \multicolumn{4}{|c|}{ Pasar Kliwon Bantul } \\
\hline lokasi & $\begin{array}{l}\text { Pasar pusat di } \\
\text { daerah Bantul }\end{array}$ & $\begin{array}{l}\text { Karak } \\
\text { teristik }\end{array}$ & $\begin{array}{l}\text { Konsumen } \\
\text { dan } \\
\text { pedagang } \\
\text { berasal dari } \\
\text { lokal dan } \\
\text { luar daerah } \\
\text { Bantul }\end{array}$ \\
\hline $\begin{array}{l}\text { Setting } \\
\text { ruang }\end{array}$ & $\begin{array}{l}\text { Pada pasar } \\
\text { hewan unggas } \\
\text { setiap hari } \\
\text { jumat kliwon } \\
\text { setting ruang } \\
\text { bertumpah } \\
\text { ruang menjadi } \\
\text { satu } \\
\text { disamping } \\
\text { pasar. Saling } \\
\text { berhimpit, } \\
\text { berkumpul dan } \\
\text { tidak teratur. }\end{array}$ & $\begin{array}{l}\text { Kegiat } \\
\text { an }\end{array}$ & $\begin{array}{l}\text { Hari jumat } \\
\text { kliwon } \\
\text { pasaran } \\
\text { hewan } \\
\text { unggas } \\
\text { ayam }\end{array}$ \\
\hline
\end{tabular}

Sumber: Analisis Penulis, 2020

Pasar Legi, Pasar Gede Solo dan Pasar Kliwon Bantul dipilih juga dengan pertimbangan kesamaan karakter pasar yaitu merupakan pasar induk dari daerah tertentu, menjadi rujukan sebagai pasar pusat, memiliki karakteristik yang sama dan hari kalender jawa sebagai ciri khas pasar tradisional.

\section{Srawung sebagai karakter khas masyarakat Kotagede}

Pengertian "srawung" (Triratnawati, 2005) adalah cara bergaul dan menyesuaikan diri dengan tidak memandang kelas sosial dalam lingkungan masyarakat. Menurut Y. Gunawan seorang Pengajar Religiositas dan Filsafat di Unika Soegijapranata Semarang (Tribun Jateng, 2016) menyebutkan bahwa srawung adalah pertemuan atau kegiatan berkumpul yang dilakukan oleh satu atau kelompok dalam lingkungan masyarakat. "Srawung" dapat menciptakan suasana rukun dan harmonis di dalam lingkungan masyarakat. (Hasyim \& Mustofa, 2017) menyebutkan kearifan lokal masyarakat Kotagede berupa pendidikan "srawung" untuk menjadi orang Kotagede. Proses Pendidikan "Srawung" didefinikan melalui tujuh lokasi pengalaman hidup, yaitu 1) ngomah, 2) lurung atau lorong, 3) langgar atau surau, 4) pasar, 5) donya jembar (dunia luas) ,6) tuk atau sumber air dan 7) makam atau jaratan. Kalimat kunci untuk memahami karakter yang menjadi ciri orang dan masyarakat Kotagede. "Sarawung marang sapadha-padha, srawung marang sakabehing titah ing ngalam donya" yang artinya bergaul dengan siapa saja, bergaul dengan segala makhluk di alam semesta. Tujuh lokasi pengalaman hidup merupakan hirarki cara bergaul dimulai dari ruang terkecil yaitu rumah yang berakhir pada lokasi pemakaman sebagai pengalaman akhir hidup.

Lokasi hirarki ke empat yaitu pasar merupakan pengalaman bergaul dengan masyarakat yang lebih luas antar lingkungan di luar lingkungan terdekatnya sekaligus merupakan pengalaman hidup berdagang sebagai salah satu lambang pekerjaan. Dasar pengalaman hidup ke empat inilah yang akan coba digali dalam Spirit of Place di Pasar Legi Kotagede.

\section{Srawung pada Pasar Legi Kotagede}

Pasar Legi memiliki hari pasaran kalender Jawa yaitu "legi", terletak di jalan Mondorakan, Purbayan, Kecamatan Kotagede Pasar Legi Kotagede. Bentuk layout dan zonasi ruang Pasar Legi Kotagede pada denah pasar (gambar 1) terdapat letak kios, los pasar, ruang pengelola dan area parkir diarea luar pasar Legi Kotagede. 


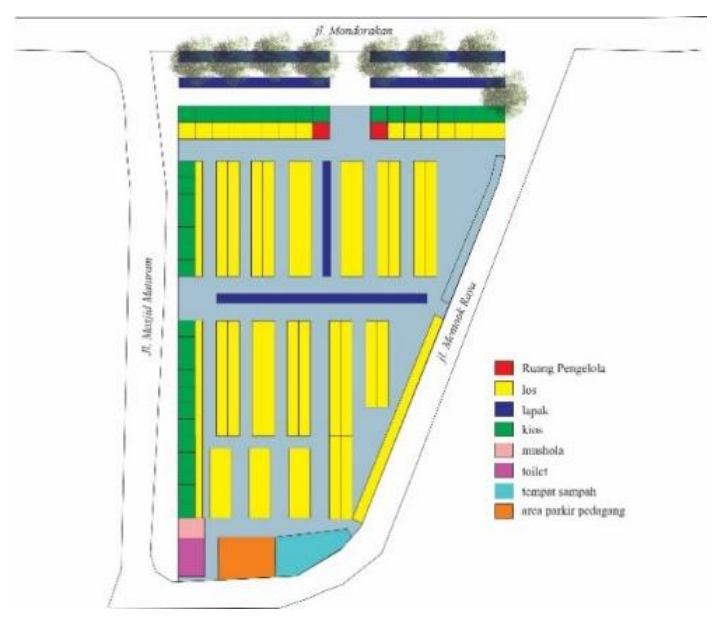

Gambar 1. Denah Pasar Legi

(Sumber: Dokumentasi Penulis, 2020)

Analisis dilakukan dengan observasi dengan mengamati fenomena lapangan serta menggambar ulang denah ruang dalam pasar Legi Kotagede. Gambar 1 menunjukkan denah dasar Pasar Legi Kotagede sedangkan gambar 2 menunjukkan zonasi berdasar komoditi. Mengingat terdapat perbedaan zonasi saat Pandemi Covid-19, maka dilakukan pula kajian perbedaan sebelum dan setelah Pandemi.

Hasil observasi yang dilakukan pada hari pasaran "Legi", sebelum dan sesudah adanya aturan Covid-19, menunjukan perubahan zonasi para pedagang. Perubahan yang terjadi yaitu area penjual jamu sudah tidak ada, penjual sayur dan buah dari area depan pindah bergeser ke bagian ruang dalam dan banyak los-los serta kios yang kosong, dan los serta lapak campuran seperti sayur buah dan makanan kering berbaur menjadi satu, penyebabnya tidak banyak pengunjung yang datang karena diawasi oleh pihak keamanan kepolisian.

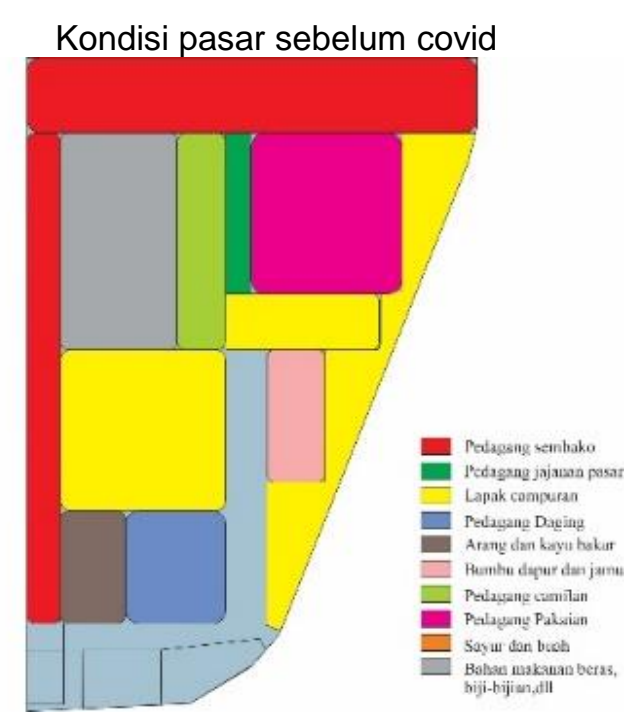

Kondisi pasar saat covid

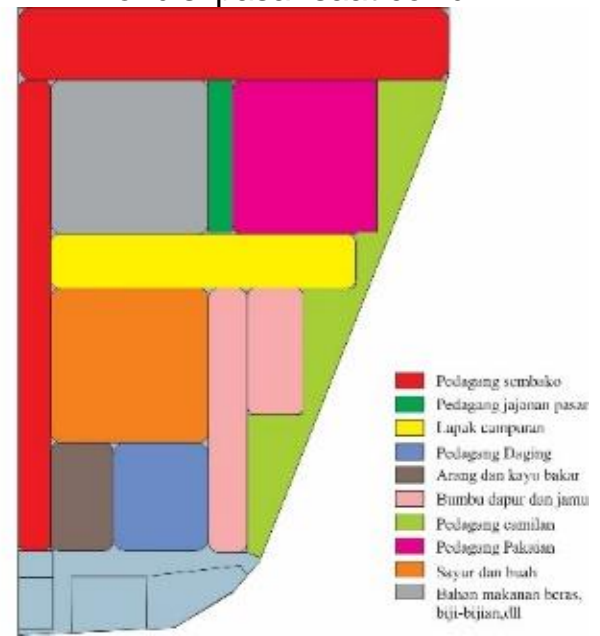

Gambar 2. Perbedaan Zonasi pedagang pada ruang dalam Pasar Legi

(Sumber: Dokumentasi Penulis, 2020)

Los ruang dalam Pasar Legi Kotagede ditempati oleh masing-masing pedagang berukuran 2,5meter $x$ 3meter, hal itu membuat mereka saling berhimpit dan terlihat berdesakan karena barang mereka yang banyak. Alhasil banyak pedagang yang berpindah dari zonasi yang seharusnya atau menumpang space sisa dari los yang sudah ada. Zonasi pedagang bahan makanan (gambar 3), beberapa los kosong, dan lorong yang sepi (gambar 4), menandakan pengunjung yang datang hanya sedikit tidak seperti biasanya padahal gambar tersebut diambil pada hari pasaran "Legi". 


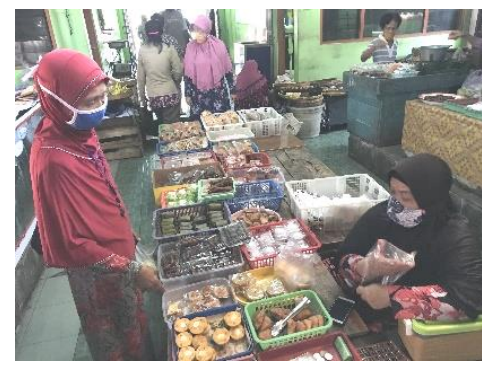

Gambar 3. Los pedagang jajanan pasar (Sumber: Dokumentasi Penulis, 2020)

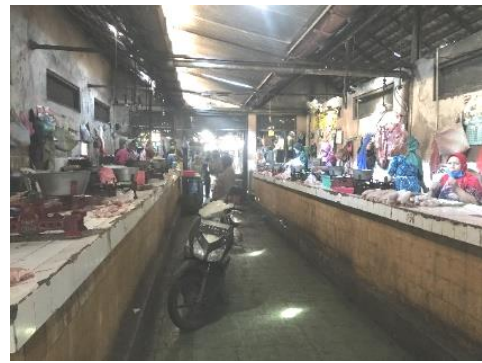

Gambar 4. Zonasi pedagang bahan makanan (Sumber: Dokumentasi Penulis, 2020)

Analisis Sprit of Place "srawung" pada Pasar Legi Kotagede dilakukan dengan cara melihat karakteristik penggunaan ruang, pelaku atau pengguna ruang (Tabel 2). Dan melakukan observasi indikasi Srawung di area Pasar Legi. Dari Tabel 2 dapat diidentifikasi ada tiga indikasi yang menunjukkan bahwa "srawung" masih dipraktekkan pada pasar Legi Kotagede yaitu 1) berbagi space /ruang, 2) saling membantu menawarkan barang dagangan, 3) saling menanyakan kabar.

Tabel 2. Analisis Sprit of Place berupa "srawung" pada Pasar Legi Kotagede

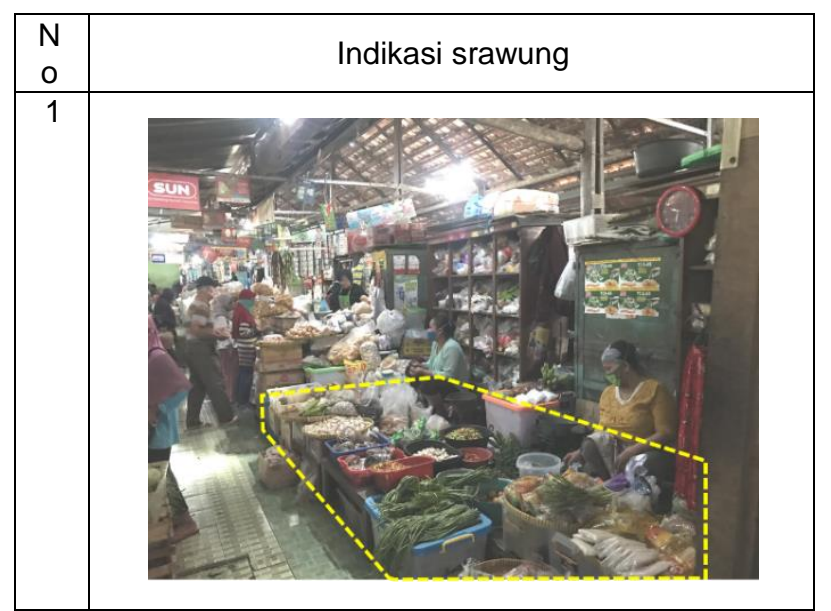

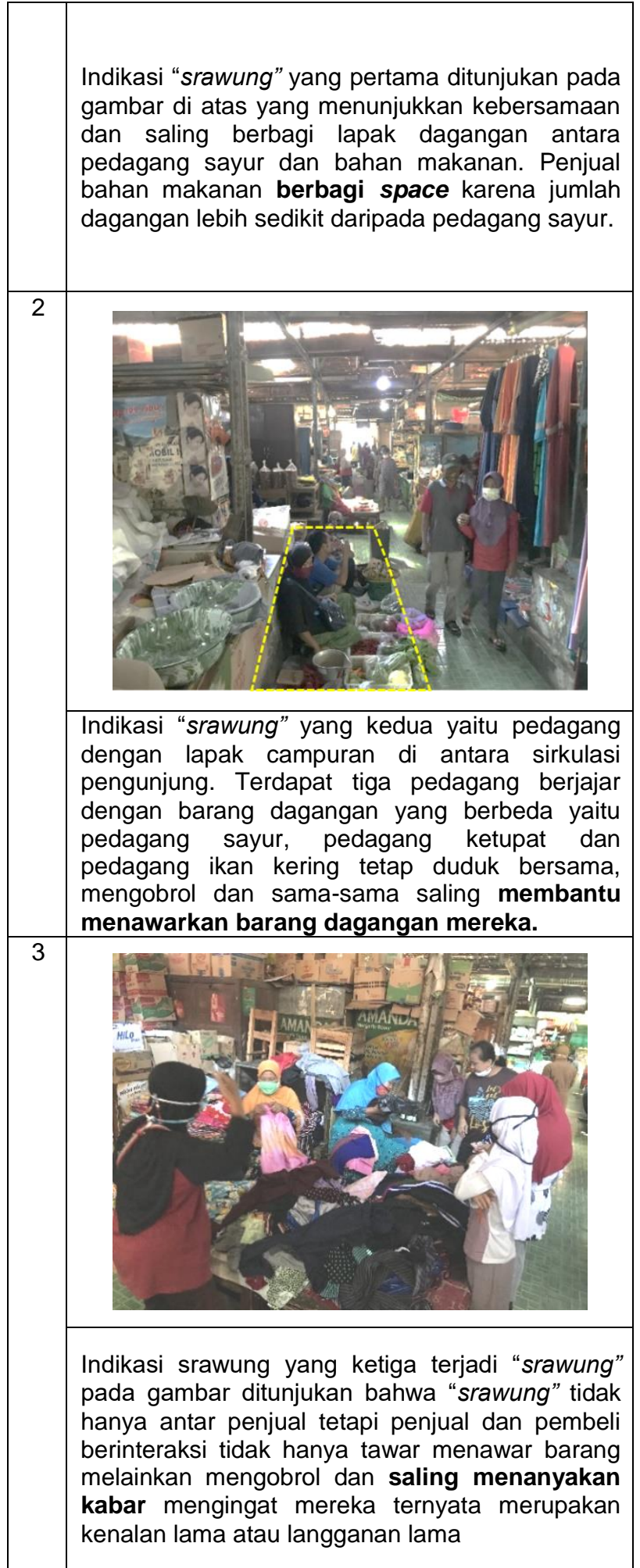

(Sumber: Analisis Penulis, 2020)

Indikasi "srawung" di Pasar Legi Kotagede masih dapat ditemukan baik sebelum pandemi dan bahkan justru setelah pandemi para pelaku di pasar semakin terlihat interaksi antar mereka. Rasa kangen sangat terlihat saat pengamatan setelah pandemi mengingat cukup lama kebiasaan yang sudah dilakukan 
hampir setiap minggu atau pekan (lima hari pasaran) yang semasa pandemi terasa dibatasi. Pandemi justru mempererat rasa senasib sehingga jarak yang ditentukan untuk keamanan selama pandemic tidak membuat takut untuk saling membantu.

Penulis melakukan studi pembanding pada dua pasar tradisional lain untuk membuktikan apakah konsep "srawung" merupakan kekhasan di Kotagede saja atau juga terjadi pada pasar tradisional lain.

\section{Studi Komparasi pada Pasar Gede Solo}

Untuk membuktikan keunikan "srawung" berupa kearifan lokal masyarakat Kotagede, maka dilakukan identifikasi dengan metode studi literatur untuk mengetahui indikasi srawung dengan cara membandingkan dengan Pasar Gede Solo. Pasar Gede yang terletak di Jalan Sudiroprajan, Kecamatan Jebres, Kota Surakarta, Jawa Tengah, dipilih sebagai pembanding karena karakteristik-nya yang sama seperti pasar Legi, pasar tradisional Gede Solo juga merupakan elemen dalam konsep Catur Gatra Tunggal dalam tata kerajaan Jawa.

(Aliyah, 2016) menjelaskan bahwa pasar Gede menjadi identitas atau ciri khas Kota Surakarta. Pada pasar Gede tidak hanya terjadi aktivitas ekonomi saja tetapi pasar ini juga sebagai meeting place atau tempat bertemu. Pasar Gede merupakan pasar yang memiliki toleransi antar etnis atau teposeliro. Dalam Pasar Gede tidak hanya berlangsung aktivitas ekonomi dan budaya saja, tetapi yang menarik adalah bahwa konsumen ataupun pedagang sengaja datang ke Pasar Gede bukan sekedar hanya untuk melakukan jual beli, tetapi juga memiliki tujuan untuk "nyambangi" atau bertemu sapa sekedar untuk mengobrol santai dan melihat situasi Pasar. Seperti halnya pada Pasar Legi di Kotagede, Pasar Gede juga memiliki karakteristik toleransi, kerukunan dan "nyambangi".

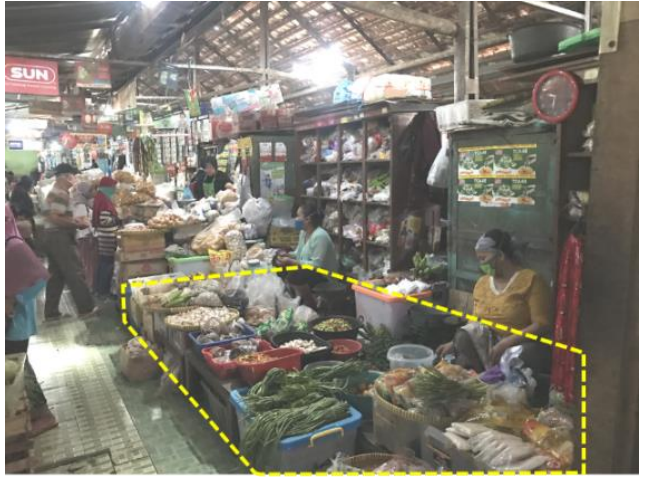

Gambar 5. Toleransi yang terjadi pada Pasar Legi Kotagede

(Sumber: Penulis, 2020)

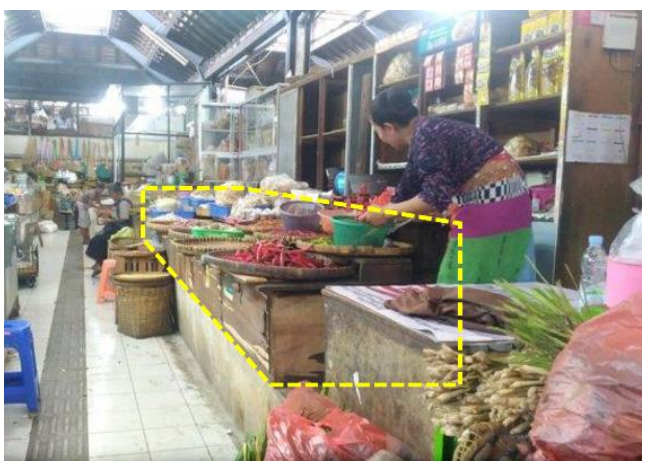

Gambar 6. Toleransi yang terjadi pada Pasar Gede Solo

(Sumber:https://jateng.tribunnews.com/2020/03/21. Diolah penulis, 2020)

Pada Pasar Legi dan Pasar Gede terjadi toleransi dan saling berbagi, terlihat dari space masing masing pedagang. Pedagang yang jumlah dagangannya sedikit menyisihkan space untuk pedagang yang masih kekurangan space karena jumlah dagangannya yang banyak.

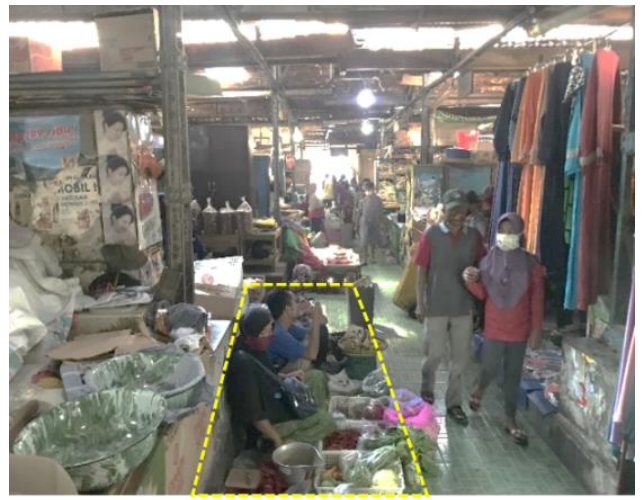

Gambar 7. Layout Pedagang pada Pasar Legi Kotagede

(Sumber: Penulis, 2020) 


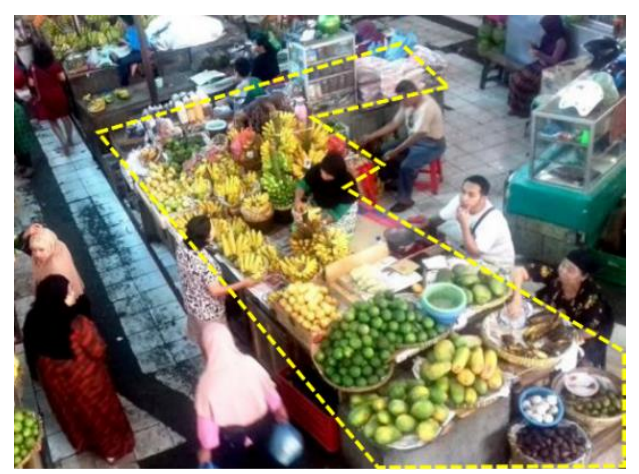

Gambar 8. Layout Pedagang pada Pasar Gede Solo (Sumber: https://solo.tribunnews.com/2016/05/05. (Diolah penulis, 2020)

Layout los-los pada Pasar Gede Solo dan Pasar Legi Kotagede terlihat pada gambar masih berhimpit dan duduk bersama, walaupun sebenarnya layout sudah sesuai standar aturan bangunan pasar.

Keakraban dan kerukunan terjadi dengan komunikasi yang baik antara sesama pedagang (gambar 9) pada Pasar Legi Kotagede. Tidak hanya antara pedagang dan pembeli ataupun sesama pedagang, pedagang pada pasar Gede Solo juga akrab melayani anak-anak TK untuk belajar bertransaksi di dalam pasar (gambar 10).

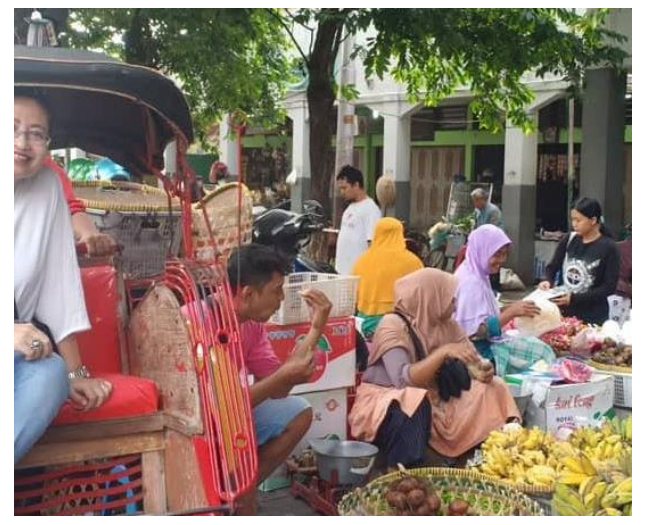

Gambar 9. Situasi Keakraban Yang Terjadi Di Pasar Legi Kotagede Antara Pedagang Dengan Sesama Pedagang

Sumber:https://www.picuki.com/tag/pasarlegikotage de. Diakses pada 11 Juni 2020

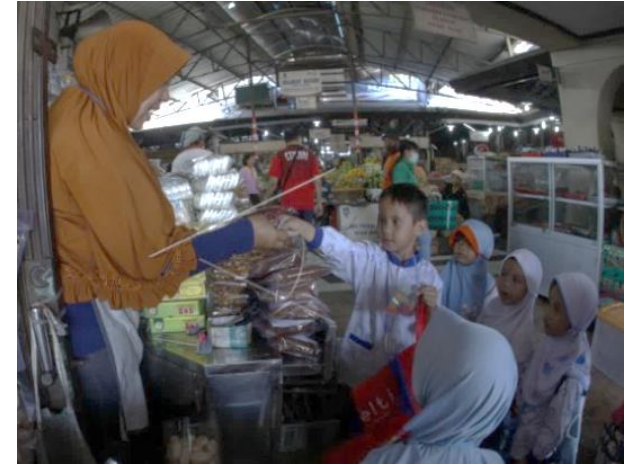

Gambar 10. Situasi Keakraban Yang Terjadi Di Pasar Gede Solo Antara Pedagang Dengan Calon Pembeli

Sumber:https://www.antarafoto.com/olahraga/v1568 186114/belajar-di-pasar-tradisional. Diakses pada 11 Juni 2020

\section{Studi Komparasi Pasar Kliwon Bantul}

Untuk membuktikan Spirit Of Place yang terjadi pada pasar tradisional dilakukan pembanding Pasar Legi Kotagede dengan Pasar Kliwon Bantul. Pasar ini dipilih sebagai pembanding dengan Pasar legi kotagede karena samasama mempunyai ciri khas atau identitas karakter budaya yang terjadi yaitu melestarikan hari pasaran sesuai kalender Jawa. Kegiatan sosial yang berkembang di pasar-pasar Kabupaten Bantul didominasi kegiatan sosial, salah satunya kebersamaan, kesopanan, kerukunan serta kemitraan merupakan nilai budaya yang mendasari kegiatan ekonomi di Pasar (Marlina et al., 2013). Pasar Kliwon Bantul mempunyai hari pasaran sesuai kalender Jawa yaitu "kliwon", yang menjadi karakter khas yaitu para pedagang hewan unggas lebih ramai dan padat pada saat hari pasaran dari hari biasanya, hal ini yang membuat Pasar kliwon banyak diminati pada hari tersebut.

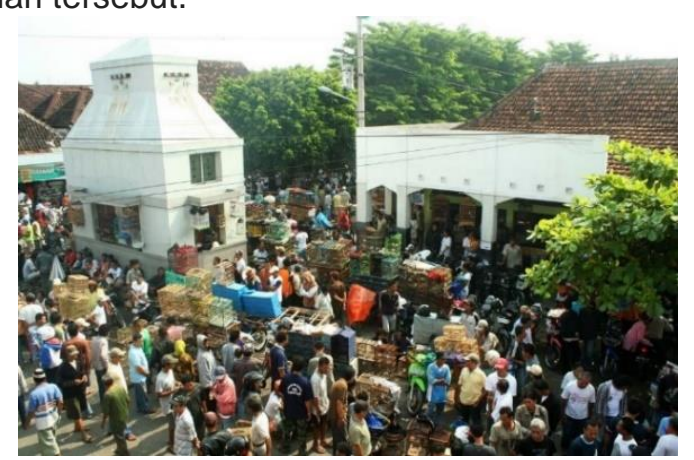

Gambar 11. Kegiatan Pedagang dan calon pembeli ayam pada Pasar Legi Kotagede. (Sumber: https://tahunpusaka.tumblr.com/post/48675500846/ pasar-legi-kotagede-di-hari-pasaran-yang-jatuh. Diakses pada 11 Juni 2020) 


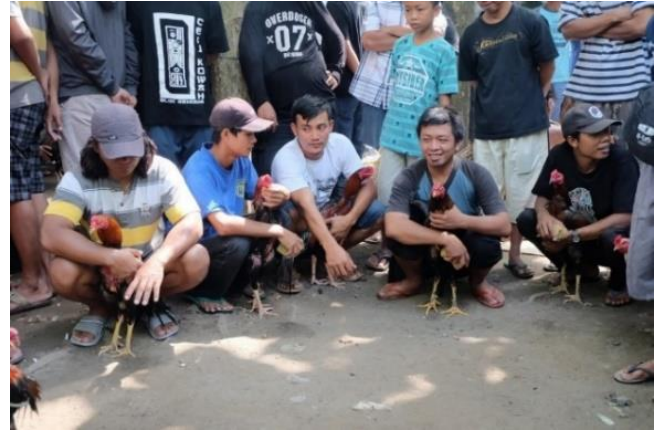

Gambar 12. Pedagang dan calon pembeli ayam pada pasar Kliwon Bantul. (Sumber: http://wargajogja.net/bisnis/uniknya-pasar-berdasarpasaran-jawa.html. Diakses pada 11 Juni 2020)

Pada Pasar legi dan Pasar Kliwon ketika hari pasaran kalender Jawa pedagang dan pembeli berbaur menjadi satu di area luar membuat kepadatan ruang pada area sirkulasi atau ruang parkir. Aktivitas pada saat kerumuman orang di pasar ini adalah saling menyapa antar pembeli, antar pedagang dan bahkan dengan petugas parkir. Identifikasi aktivitas berupa "srawung" dengan saling menyapa pada pasar dapat terjadi mengingat cukup banyak orang saling mengenal satu dengan yang lain. Bahkan warga pengguna pasar seringkali menjadikan pasar sebagai kegiatan saling berkabar antara pengguna ruang pasar. "Srawung" diwujudkan karena adanya rasa kebersamaan, tenggang rasa dan kepedulian yang saling terikat di Pasar tradisional. "tuna satak bathi satak" merupakan sebuah peribahasa Jawa yang peribahasa jawa yang menggambarkan suasana antara penjual dan pembeli dalam Pasar Tradisional, yang artinya "tidak mengapa merugi sedikit asalkan mendapat saudara" (Kompasiana.com, 2018).

Para pedagang unggas dan pembelinya tidak hanya sekedar mencari untung atau mencari hewan peliharaan saja tetapi mencari relasi atau hubungan kekerabatan yang akan mengakrabkan mereka. Terbukti dengan adanya kegiatan latihan sabung ayam dan berbagi cara merawat ayam atau unggas.

\section{"Srawung" sebagai Spirit of Place Pasar Legi Kotagede}

Dari komparasi antara Pasar Legi Kotagede, Pasar Gede Solo dan Pasar Kliwon Bantul disimpulkan bahwa sebenarnya keakraban yang terbangun antar pembeli dan penjual serta antar sesame pembeli dan sesame penjual merupakan kearifan lokal yang terdapat di pasar tradisional di Jawa Tengah dan DIY. Akan tetapi konsep "Srawung" pada pasar yang merupakan salah satu bagian pendidikan pengalaman hidup hanya terdapat di Kotagede, sehingga dapat dikatakan bahwa srawung merupakan spirit of place Pasar Legi dan bukan Spirit of Place pasar tradisional.

\section{KESIMPULAN}

Dari hasil analisis dan pembahasan melalui observasi dan studi literatur, dapat disimpulkan bahwa Spirit of Place yang terjadi pada Pasar Legi Kotagede adalah "srawung" yang menjadi karakteristik budaya lokal.

Dengan studi observasi yang dilakukan pada Pasar Legi dan membandingkan ketika sebelum covid dan saat covid, kondisi pandemi tidak berpengaruh pada kegiatan "srawung" yang meliputi tawar menawar, saling membantu, mengobrol, serta menyapa yang terjadi antara pedagang dan pembeli.

Dengan membandingkan karakteristik lokal Pasar Legi Kotagede, Pasar Gede Solo diketahui bahwa "nyambangi" adalah bentuk kata lain dari "Srawung" pada Pasar Gede. Pada pasar Gede berlangsung aktivitas antara pedagang dan pembeli yang datang ke Pasar Gede bukan sekedar hanya untuk melakukan jual beli, tetapi juga memiliki tujuan untuk "nyambangi" atau bertemu sapa sekedar untuk mengobrol santai dan melihat situasi Pasar.

Pada kedua pasar analisis menghasilkan kesamaan pada layout ruang dan aktivitas pengguna berupa cara berinteraksi tawar menawar barang, mengobrol dan saling menanyakan kabar, pedagang dengan barang dagangan yang berbeda tetap duduk bersama, mengobrol dan sama-sama saling membantu menawarkan barang dagangan mereka, kebersamaan dan toleransi antar pedagang saling memberi ruang untuk pedagang yang kurang akan kebutuhan ruangnya.

Pasar unggas ayam pada Pasar Kliwon dan Pasar Legi yang menjadikan pelaku kegiatan menjadi lebih akrab dan berbagi pengalaman dan ilmu dalam bidang merawat ayamnya. Penataan layout, zonasi pedagang serta sikap saling toleransi, keakraban, kerjasama dan peduli antar pedagang maupun pembeli.

Kendati berbeda istilah antara "nyambangi" dan "srawung" tetapi kualitas kegiatan yang dihasilkan sama, sehingga Spirit of Place berupa keakraban dapat disimpulkan menjadi karakteristik sebuah pasar tradisional. Sementara itu Spirit of Place berupa "srawung" 
yang ada di Pasar Kotagede membentuk identitas atau karakter dari kearifan lokal masyarakat Kotagede.

\section{DAFTAR PUSTAKA}

Aliyah, I. (2016). The Roles of Traditional Markets as the Main Component of Javanese Culture Urban Space (Case Study: The City of Surakarta, Indonesia). IAFOR Journal of Sustainability, Energy \& the Environment, 3(1), 103-120. https://doi.org/10.22492/ijsee.3.1.06

Garnham, H. L. (1985). Maintaining the Spirit of Place. PDA Publishers Corporation.

Harapan, S. (2011). Kajian Spirit of Place Kampung Madras Medan. 7-24.

Hasyim, H., \& Mustofa. (2017). Srawung: kearifan Lokal Dari Kotagede. Prajnaparamita Jurnal Museum Nasional, 77-86.

Herliana, E. T. ... Kusuma, H. E. (2017). Cultural Attachment sebagai Pembentuk Sense of Place Kampung Bugisan, Yogyakarta. Seminar Ikatan Peneliti Lingkungan Binaan Indonesia (IPLBI), C001-C008.

https://doi.org/10.32315/sem.1.c001

Kompasiana.com. (2018). Bingkai "Tuna Satak, Bathi Sanak" dalam Pasar Tradisional. Retrieved from https://www.kompasiana.com/sangpema ndu/5a89a8ebcbe5234a64391e83/bingka i-tuna-satak-bathi-sanak-dalam-pasartradisional

Kostof, S. (1992). The City Assembled. London: Thames \& Hudson.

Laws, F. P. (2016). Sekilas Mengenai Tata Ruang Kota Gede Yogyakarta. Retrieved from

http://farizpradiptahistoryandculture.blogs pot.com/2009/12/sekilas-mengenai-tataruang-kota-gede.html

Marlina, E. ... Dharoko, A. (2013). Pasar: Simpul Persebaran Budaya Di Kabupaten Bantul, Daerah Istimewa Yogyakarta. Jurnal Tataloka, 15(2), 91. https://doi.org/10.14710/tataloka.15.2.91101

Rahmawati, D. A., \& Kartono, D. T. (2017). MODAL SOSIAL DAN PASAR TRADISIONAL (Studi Kasus di Pasar Legi Kotagede Yogyakarta). Jurnal Sosiologi DILEMA, 32(2), 10-19.

Tribun Jateng. (2016). Melestarikan Budaya Srawung. Retrieved from http://jateng.tribunnews.com/2016/11/05/ melestarikan-budaya-srawung

Triratnawati, A. (2005). Konsep Dadi Wong Menurut Pandangan Wanita Jawa.
Humaniora, 17(3), 300-311. https://doi.org/10.22146/jh.v17i3.855 
